\title{
Students' Perspectives on Concepts, Factors, and Models Related to the Attainment of Achievement
}

\author{
Titik Kristiyani \\ Faculty of Psychology \\ Universitas Sanata Dharma
}

\author{
Faturochman \\ Faculty of Psychology \\ Universitas Gadjah Mada
}

This study aimed to explore concepts, factors affecting, and achievement models, from the perspective of tertiary students in Yogyakarta. Respondents $(N=533)$ were students of a private university in Yogyakarta. Data was collected through an open-ended questionnaire for all respondents, and in-depth interviews with 23 of these. Data were analyzed using content analysis techniques for responses to the answers provided. The results show that the concept of achievement, according to the perspective of the students, is differentiated between into definitions of achievement, and the criteria of what may to be considered to be achievements. The definition of achievement, according to the students, is something which is unique to this finding, with the emergence of non-academic achievement and excellence in competition with others. The criteria discovered, for a person to be considered to be an achiever, include compliance with goals (both personal and social) and the presence of the element of development. The presence of the suitability of social goals, is another unique thing found in this study. Factors which influence achievement include 'input' (personal capacities), and 'process' (the learning process)'. The external conditions which emerged in this finding took the form of other unique matters, found in the local culture. The dynamics of reaching achievement begin with 'input' (cognitive capacity, personal skills, motivation), and external conditions (which give rise to academic learning behaviors with the support of self-efficacy), for future learning achievements which are more optimal, with the attainment of personal and social goals.

Keywords: achievement, input, process, output

Penelitian ini bertujuan mengesplorasi konsep, faktor pengaruh, serta model perolehan prestasi menurut perspektif mahasiswa. Responden $(N=533)$ adalah mahasiswa suatu perguruan tinggi swasta Yogyakarta. Data dikumpulkan melalui kuesioner terbuka pada semua responden dan wawancara mendalam kepada 23 responden. Data dianalisis dengan teknik analisis isi atas respons-respons jawaban yang ada. Hasil menunjukkan bahwa konsep prestasi menurut perspektif mahasiswa dibedakan menjadi definisi prestasi dan kriteria untuk dianggap sebagai prestasi. Definisi prestasi menurut mahasiswa adalah capaian, yang memiliki keunikan dalam temuan ini dengan munculnya prestasi non-akademik serta ke-unggulan dalam kompetisi dengan orang lain. Kriteria berprestasi meliputi kesesuaian dengan tujuan (pribadi dan sosial) serta adanya unsur pengembangan. Adanya kesesuaian dengan tujuan sosial merupakan hal unik lain yang ditemukan dalam penelitian ini. Faktor yang memengaruhi prestasi meliputi masukan (kapasitas personal) dan proses (meliputi proses belajar). Kondisi eksternal yang muncul merupakan keunikan lain dalam budaya setempat Dinamika perolehan prestasi dimulai dari masukan ( kapasitas kognitif, skill personal, motivasi), dan kondisi eksternal (yang memunculkan perilaku belajar akademik dengan dorongan efikasi diri), untuk selanjutnya diperoleh prestasi belajar yang akan lebih optimal dengan adanya tujuan pribadi dan sosial.

Kata kunci: prestasi, masukan, proses, luaran

For students, achievement, which is mainly perceived in terms of learning outcomes, is the goal of their

Correspondence concerning this article should be addressed to Titik Kristiyani, Faculty of Psychology, Universitas Sanata Dharma Paingan Maguwoharjo Depok Sleman, Yogyakarta 55281. E-mail: titikpsy@usd.ac.id studies. Achievement in education has many benefits in everyday life. Academic achievement is considered to be an important determinant for further education and careers (Von Stumm, Hell, \& Chamorro-Premuzic, 2011). Undoubtedly, before deciding to accept or re- 
ject a university graduate, employers of such a graduate will make predictions regarding the ability of said graduate, from his or her Grade Point Average (GPA), which is considered to reflect his or her academic achievement. Besides their effects in the formal sphere, academic achievements also have an effect on the friendship dynamic which is formed between people having similarities in academic achievements (Flashman, 2012).

Although achievement is often interpreted as being results, previous literature reviewed found three separate aspects of the definition achievement, which are related to results, processes, and personal characteristics. In the aspect of results, achievement is perceived as the acquisition of knowledge, skills, expected competencies, mastery of learning outcomes, and performance (Arum \& Roksa, 2011; Choi, 2005; Galyon, Blondin, Yaw, Nalls, \& Williamn, 2012), and also the attainment of a high GPA (DeFreitas \& Bravo, 2012). Dhaqane and Afrah (2016) claimed the satisfaction and subjective assessment of self-achievement as being a definition of achievement. From the aspect of 'process', achievement is a form of involvement in learning activities, both physically and cognitively (Cole, 2009; Gurin, Dey, Hurtado, \& G. Burin, 2002). The aspect of personal characteristics includes mental abilities, academic skills, motivation and goals, intellectual development, emotional intelligence, hard skills and soft skills, and individual resilience (Gurin, Dey, Hurtado, \& G. Guin, 2002).

Besides showing variations in the definitions of achievement, the three main aspects of achievement summarized by a number of researchers come from varied cultures in many countries in the world. Each culture has different aspects of emphasis. For example, American researchers tend to measure achievement qualifications from success in completing a course, marked by a good GPA, while Japanese and Chinese researchers measure achievement from performance in certain skills (Harold, Shin-Yin, \& James in Yusuf, 2002). Other researchers use accountability as an indication of learning outcomes, which are defined as extending beyond cognitive assessment, and include attitudes and values held (Dagnew, 2017). The conceptual problem arising from research into achievement has been related to measurement problems. This has occurred because researchers have different orientations in the perception of achievement, and there is no literature providing definitive clarification of these differences in orientation. This is indicated by the difficulty of finding a consensus about the definition of achievement, namely in relation to academic performance, academic achievement, and learning outcomes (Yusuf, 2002).

The differences in the concept of achievement and measurement, between researchers, have had an impact on the variety of research results into factors affecting achievement. These could be classified as both internal and external factors. The internal factors include intelligence, academic rigour and intellectual curiosity (Von Stumm, Hell, \& Chamorro-Premuzic, 2011); the understanding of hope (Ugwu, 2017); academic self-efficacy (Valiente, Eisenberg, Spinrad, Haugen, Thompson, \& Kupfer, 2013), and; perception of the control of effort (You, Hong, \& Ho, 2011). External factors include; family support, lecturer support, friendships with academically successful people, family financial support (Goguen, Hiester, \& Nordstrom, 2010; Orrock \& Clark, 2015; Ugwu, 2017), and teaching methods (Schmid, Bernard, Borokhovski, Tamim, Abrami, Wade, Surkes, \& Lowerison, 2009).

An understanding of the predictors of achievement will be greater if supplemented with an explanation of how the pattern of achievement is realized. The theoretical model of academic success according to Astin (1993), known as the Input-Environment-Outcome (I-E-O) model, states that learning achievement, in higher education, is a function of three elements, the stated input, environment, and outcome (see Figure 1).

Input elements include demographic factors, family background, and previous academic and social experiences brought to the tertiary education system. The environmental element includes the various people in the environment of a student, programmes, policies, cultures, and tertiary educational experiences. The outcome elements include characteristics of the student,

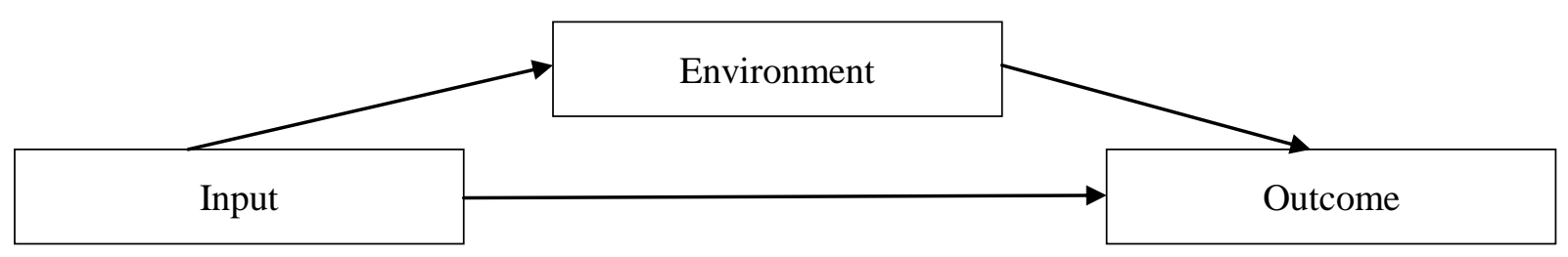

Figure 1. Model I-E-O (Astin, 1993) 
knowledge, skills, attitudes, values, beliefs, and behaviors formed after students graduate (Pascarella \& Terenzini, 2005). The Astin model of academic success is constructed from a definition of academic achievement in certain contexts. The data used to construct the I-E-O model by Astin originated from a United States data base. As explained earlier, American and Japanese or Chinese researchers have differences in their understanding and measurement of this concept of achievement (Yusuf, 2002). Thus, it is necessary firstly to understand the concept of achievement as understood in the region to be studied, before implementing the Astin model, in regions outside the United States.

To date, the majority of research about the learning process has been conducted in the context of one or more Western cultures (Purdie in Turingan \& Yang, 2009). These studies used instruments with specific domains. Studies show differences in characteristics between Asian and American students. Asian students have been found to be more reactive in using a learning approach, and more dependent on lecturer instruction, than on taking the initiative to undertake individual study. For example, Japanese students are more dependent on external sources in managing their learning than are Americans. Asia cultures show interdependence, while American culture is more individualistic (Turingan \& Yang, 2009). Students from Eastern cultures (Asia) are more motivated to learn, because of a strong desire to improve their socio-emotional statuses, family dignity, to receive lecturer and parental appreciation, and to obtain good employment. Cultural differences in Western and Eastern countries may influence the diversity of thinking patterns and life values, which in turn will have an impact on perceptions and strategies in learning. Extant comparative studies related to variables in intercultural education examined that of Korea and the Philippines, for the Asian region. This current study was conducted in Indonesia, which, despite being located in the Asian region, has an education system somewhat different from those of the previously mentioned countries. In reality, different cultural structures have different impacts on different educational systems (Marginson \& Mollis, 2000).

This aside, the definition, benefits, and predictors of academic achievement theories have been constructed from the lecturer perspective, not from that of the tertiary student. This study attempted to explore the concept of achievement from the perspective of the student. There have not as yet been any studies aimed at exploring the concept of achievement. Most studies have aimed to correlate many variables with achieve- ment, in order to determine achievement predictors. A study whose aim is closer to that of this current study is that conducted by Yusuf (2002), but it focuses more on the variety of terms of achievement, and their measurement. The article written by York, Gibson, and Rankin (2015) is also similar to this study, examining the benefits of academic success in various fields. However, the York, Gibson, and Rankin (2015) article is a literature review, rather than being empirical research, as was conducted in this study.

An understanding of the concept of achievement, from the perspective of the tertiary student, may determine how educators make assumptions, and what they expect regarding the learning behavior of their students. This is the reason that understanding the concept of achievement from the perspective of the student, the factors seen to influence that, and the achievement model, are important matters warranting examination, in order to improve the quality of tertiary education in Yogyakarta. Therefore, this current study was focused on exploring the perspective of students regarding concepts, influencing factors and achievement models, by employing the following three research questions: (1) What is the perspective of Yogyakarta tertiary students, concerning achievement?; (2) What are the factors influencing achievement, according to the perspective of these students, in Yogyakarta?; (3) What is the achievement model, from the perspective of tertiary students in Yogyakarta?

\section{Method}

This current study aimed to achieve a better understanding of Human students, with all their unique qualities. The aim was to explore concepts, influencing factors, and models of achievement, from the perspective of tertiary students in Yogyakarta. This goal was achieved by using indigenous psychological approaches, which try to understand human behavior, without ignoring the context for the emergence of these behaviors. Psychology needs to look at humans from various perspectives (Singh, 2002). This study does not attempt to reveal de-contextualised, mechanistic, and universal principles, but seeks to uncover the universality of psychology in certain social, cultural and ecological contexts (Kim, Yang, \& Hwang, 2006). This approach is not the same as that of cross-cultural psychology, which uses psychological and mainstream concepts to view and understand psychology in a particular culture. Indigenous psychology places more emphasis on the originality of psychological concepts 
existing in a particular culture (Hakim, 2014).

The respondents were 533 undergraduate students at a private university in Yogyakarta. These students were gathered randomly by approaching the lecturers in certain study programmes, and asking permission to distribute questionnaires in the classes taught by them. The appropriate times for data collection were arranged, depending upon agreements made with each lecturer, so the completion of the questionnaire was not conducted simultaneously for all respondents. Before the respondents were asked to fill out questionnaires, the researchers first provided an overview of the purpose of the data collection, and the voluntary nature of the completion of the questionnaire. The researchers asked the respondents to state their willingness, or unwillingness, to be involved in the research. The respondents were drawn from several study programmes of the Teacher Training and Education Faculty, the Psychology Faculty, the Arts Faculty, the Pharmacy Faculty, and the Faculty of Science and Technology.

The study employed mixed methods, combining both qualitative and quantitative. There were two types of instruments employed to collect data for the study, an open-ended questionnaire, which required a duration of about 30 minutes for completion, and in-depth interviews, which required from 30 minutes to one hour for completion by each randomly selected respondent. To obtain a deeper understanding of the interview results, researchers recorded the interview processes. Interviews were conducted employing semi-structured methods. Open questionnaires were given to all respondents. Each respondent wrote his or her response on the paper provided. Completion of questionnaires was carried out on campus for each class. In-depth interviews were conducted with 23 respondents, who were randomly selected from the study programmes, where the researchers selected one completed questionnaire from each study program, in 'reverse conditions', so that they did not know the identity of the person who had completed the selected questionnaire.

\section{Results}

From the 533 respondents, there were 881 response variations, with 55 responses having no meaning, so the total number of responses used was 826 . From these 533 respondents, 23 underwent in-depth interviews.

\section{The Theme Research Result}

The themes found in this study can be grouped in- to three categories, namely those of 'input', 'process', and 'output'. The grouping was based on the similarity of the characteristics of the themes. The first category was 'input', interpreted as prerequisite conditions, or modalities of emergence of behaviors, leading to achievement. This category includes responses containing themes of personal motivation, skills, selfefficacy, cognitive capacity, and external conditions.

These themes were the conditions, both internal and external, mentioned by respondents when they identified their own achievements. Motivation, personal skills, self-efficacy, and cognitive capacity are the internal conditions of individuals which are often associated with achievement. The external conditions associated with achievement included those covering characteristics of the course, lecturers, friends, and the non-academic burden. The total number of responses showing 'input' conditions was 206 , or $24.9 \%$ of all the responses, the smallest number from all categories.

The second category, the 'process', included activities leading to achievement, and consisted of learning processes and standard task-completion themes. These two themes covered learning activities, both those independently undertaken outside the classroom and those undertaken actively, in classroom learning. The total number of responses for this category was 256 or $31 \%$ of the overall responses.

The next category comprised themes showing an outcome, that is the 'output' themes, including attainment, goals, and development. Achievements included learning outcomes, both in quantitative and qualitative forms. Goals comprised both personal and social goals. Development was seen as results, judged by standard criteria, not only academic but also non-academic achievement. The frequency of themes found in this study was determined, to calculate the popularity of each of these themes, among the respondents. The responses in the 'output' category showed the greatest frequency (364 or $44.1 \%$ ). This means that attainments, and other tangible matters, are perceived more as achievements, compared to themes falling into other categories. A summary of themes, regarding achievement from the student perspective, can be seen in Table 1.

\section{Achievement Concepts, from the Perspective of Undergraduate Students}

Of the three achievement categories resulting from this study, the concept of achievement is categorized as 'output', including the themes of attainments, goals, and development. These three themes can be divided 
Table 1

Themes of Achievement

\begin{tabular}{lcccc}
\hline Themes & $f$ & $\%$ & Category & Total (\%) \\
\hline Motivation & 117 & 14.2 & input & $206(24.9 \%)$ \\
Personal Soft skill & 24 & 2.9 & input & \\
Self efficacy & 23 & 2.8 & input & \\
Cognitive capacity & 23 & 2.8 & input & \\
External conditions & 19 & 2.3 & input & $256(31.0 \%)$ \\
Learning process & 231 & 28.0 & process & \\
Standard task completion & 25 & 3.0 & process & $364(44.1 \%)$ \\
Attainment & 289 & 35.0 & outcome & \\
Goal & 65 & 7.9 & outcome & \\
Development & 10 & 1.2 & outcome & \\
Total & 826 & $100 \%$ & & \\
\hline
\end{tabular}

Table 2

Achievement Definition, from the Undergraduate Student Perspective

\begin{tabular}{lcccc}
\hline Achievement definition & $f$ & $\%$ & Level & Total (\%) \\
\hline Grade/ GPA & 46 & 15.9 & standard & standard \\
Mastery of subject & 36 & 12.5 & standard & \\
Attainment of target & 29 & 10.0 & standard & standard \\
Achievement stability & 24 & 8.3 & above standard & $47(16.3 \%)$ \\
Increase in knowledge & 3 & 1.0 & above standard & \\
Increase in grades & 40 & 13.8 & above standard & $104(36.0 \%)$ \\
Non-academic achievement & 4 & 1.4 & satisfying and competitive & \\
Knowledge application & 3 & 1.0 & satisfying and competitive & \\
Satisfying result & 52 & 12.8 & satisfying and competitive & \\
Maximum result & 37 & 1.2 & satisfying and competitive & \\
Better than friends & 12 & 1.0 & & \\
Academic competition & 3 & $100 \%$ & & \\
Total & 289 & &
\end{tabular}

into the definitions of achievements and achievement criteria. Based on Table 1, the definition of achievement can be seen in the attainment theme (289 responses), while the achievement criteria are found in goals and development (totaling 75 responses). From the 289 responses classified under attainment, there were three levels of achievement, namely 'standard', 'above standard', and 'satisfying and competitive'. This can be seen in Table 2 .

This classification is based on the depth level of achievement meaning, conducted by researchers with supervision and correction from a senior researcher in qualitative research and indigenous psychology. 'Standard' level is the lowest, which perceives achievement as tangible things, such as grades/GPA, mastery of subjects, attainment of targets, achievement stability, and increases in knowledge. This received the most responses of all the levels (47.8\%). The following are interviews results describing 'standard' levels:

\footnotetext{
"...I say eight because of what I see from the GPA..." (grade/GPA)
}

"...I see it from... of course GPA" (grade/GPA)

"My GPA is not optimum yet" (grade/GPA)

"I understand better" (mastery of subject)

"Can't master everything" (mastery of subject)

"... when saying I cannot take it, actually I can... I still can take it" (mastery of subject)

"The problem is if it passes through the target, it's already passed through the target" (attainment of target)

"...hasn't met expectations" (attainment of target)

"When my grade pass through what has been set" (attainment of target)

"Other expectations have not been met" (attainment of target)

"My academic achievements tend to fluctuate. Sometimes in the first semester it is good, then later when it is mid-semester it can drop dramatically, sometimes it will continue to increase again later" (achievement stability)

"The knowledge that I got is there..." (increase in knowledge)

"...my knowledge developed..." (increase in knowledge) 
Achievement is considered to be at a level above 'standard' when grades have increased, which reflects better mastery and application of the material. The ability to apply knowledge was seen not only in the academic area, but also in non-academic attainments. Achievements at this level had the smallest number of responses, that is 47 , or $16.3 \%$ of all the levels. This means only a few students recognized achievement in the form of increasing grades, non-academic achievements, and the application of knowledge. The following are interviews results describing the perception of achievement at the level above 'standard':

"It's not really increasing, but I'm really feeling that there is an increase, but not really, it's not significant" (increase in knowledge)

"...not only good grades, but also ability to apply." (knowledge application)

"It's not just in the academic field, achievements can come from anywhere, such as talent in art" (nonacademic achievement)

Achievement was seen as being at a satisfying and competitive level when students felt they had achieved the maximum results possible. This maximum perception was indicated by the ability to exceed the achievements of friends, or at least those at the highest level among friends. This condition produced satisfaction. The total number of responses indicating this level was 104 , or $36 \%$, ranking second after those showing the 'standard' level. In interviews, achievements at this level are indicated by the following quotes:

"I think it is extraordinary, compared to my friends" (better than friends)

"My academic achievements during college are really good... the subject is very satisfying" (satisfying results)

"When a friend says it's not possible, I try and try to be better, to beat the others" (academic competition) "My friends has respect for me... you... you can do that, so recognition from friends also shows my achievements" (better than friends)

Referring to Table 1, the achievement criteria, as part of the outcome, included goals and development, with a total response of 75 . Based on these findings, it maybe concluded that an attainment can be regarded as an achievement if it meets at least two criteria, namely targeted goals and development. Table 3 shows the percentage of responses to performance achievement criteria.
Table 3

Criteria of Output Achievement

\begin{tabular}{lccr}
\hline Criteria & Themes & $f$ & $\%$ total \\
\hline Goal & Personal goals & 53 & 86.7 \\
& Social goals & 12 & \\
Development & Non-academic activities & 10 & 13.3 \\
& $\quad$ Total & & 100 \\
\hline
\end{tabular}

Based on the findings in this study, student performance could be said to have been achieved if the outputs were in line with the initial goals. Goals could be both personal and social goals. Having goals, for students, was the greatest criterion for attaining a good achievement $(86.7 \%)$. This meant that goals were very important things for students. In addition to goals, the achievement outcome criteria found in this study were those regarding development. Participation in non-academic activities was a theme found in these criteria. Some expressions showing the importance of goals and development included:

"The balance between my academic and other activities, such as developing my soft skills and my hard skills" (non-academic activities)

"It's not just from academic activity, achievements can be from anywhere. Like for example that person has a talent in art" (non-academic activities)

The findings on the definition of achievement, according to undergraduate students in Yogyakarta, can be formulated in an achievement model, as shown in Figure 2.

\section{Factors Affecting Achievement}

Based on the themes found, factors influencing achievement could be identified, grouped into 'input' factors and 'process' factors. 'Input' factors included cognitive capacity, personal skills, motivation, and external conditions, whilst 'process' factors included fulfilling standard tasks and the learning processes. Table 4 shows a summary of the 'input' factors influencing achievement.

As shown in Table 4, 'input' factors can be grouped into internal and external factors. There are internal factors included in inherited conditions and conditions which can be controlled. Conditions which can be controlled, namely personal skills and motivation, made a greater contribution $(77.1 \%)$ than those which are innate, which contribute to cognitive capacities, namely thinking and memory abilities (12.6\%). The following were expressions of input factors which were 


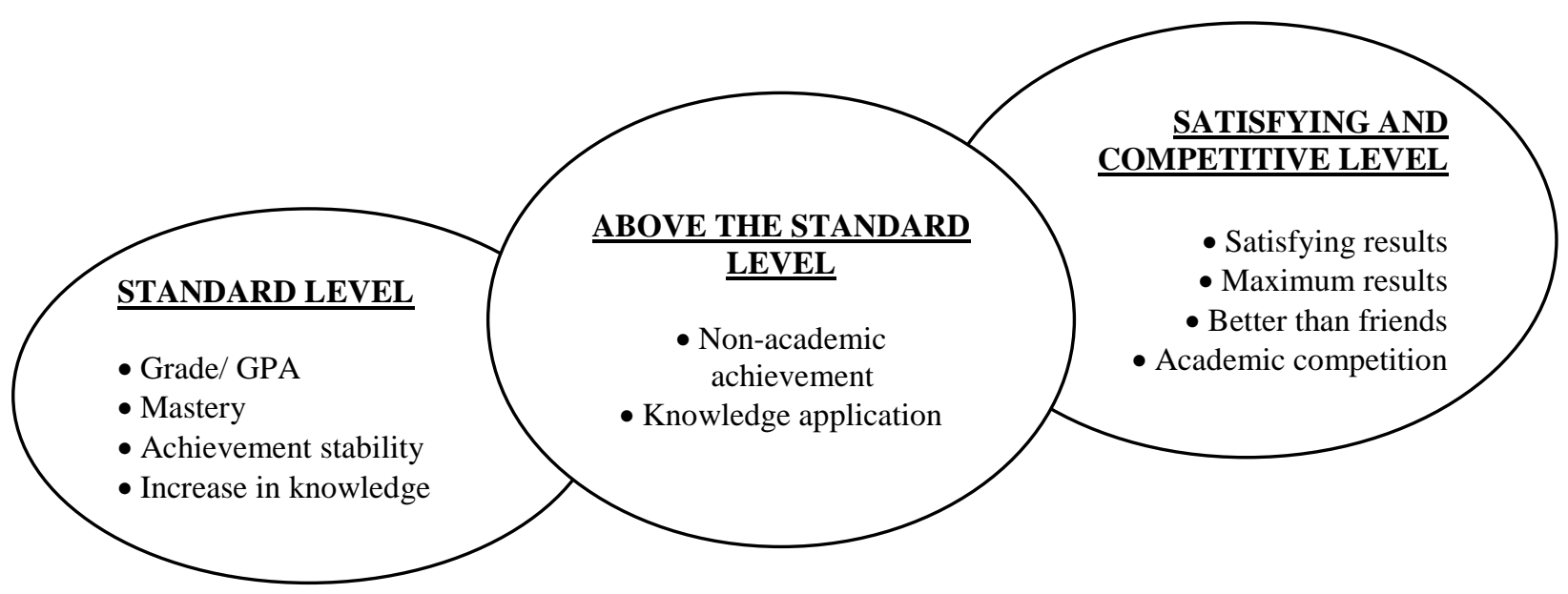

Figure 2. Achievement model, from an undergraduate student perspective.

Table 4

Input Factors Affecting Achievement

\begin{tabular}{lcccr}
\hline Input factor & Categorization & $f$ & $\%$ & \% cumulative \\
\hline Cognitive Capacity & Thinking ability & 17 & 9.3 & 12.6 \\
Personal Skill & Memory ability & 6 & 3.3 & 13.1 \\
& Self-management & 8 & 4.4 & \\
& Adjustment & 6 & 3.3 & \\
& Self confidence & 4 & 2.2 & \\
Responsibility & 3 & 1.6 & 64.0 \\
Motivation & Assertiveness & 3 & 1.6 & \\
& Intention to learn & 73 & 39.9 & \\
& Interest in majors & 14 & 7.7 & \\
& Learning stability & 12 & 6.6 & 10,3 \\
External Condition & Eagerness for better understanding & 6 & 3.3 & \\
& Eagerness to add new knowledge & 6 & 3.3 & \\
& Value & 5 & 2.7 & \\
& Altruistic motivation & 1 & 0.5 & $100 \%$ \\
& Characteristics of course & 8 & 4.4 & \\
& Characteristics of lecturers & 5 & 2.7 & \\
& Number of non-academic loads & 3 & 1.6 & \\
& Characteristics of friends & 3 & 1.6 & \\
& Total & 183 & $100 \%$ &
\end{tabular}

perceived as affecting achievement:

"...interested in physics, the intention starts, there is an intention to learn." (motivation)

"Less than optimal, because of long-term adaptation" (personal skills)

"...poor in memorizing..." (cognitive capacity)

"From friends' opinions, and also from the lecturers' feedback" (external conditions)

In the process factor, there were two factors affecting achievement, namely the completion of standard tasks and the learning process. Table 5 shows a summary of process factor categories.
The completion of standard tasks is a standard matter undertaken by students, in order to obtain achievement, and is more responsive to the class stimulation, whilst the learning process is interpreted as an active effort made by students, both in indoor and outdoor activities. Between the two process factors, the learning process factor was that showing the highest percentage $(86.8 \%)$. The following are quotes from interviews about the role of the learning process in determining achievement:

"From the learning process, how to learn it..." (management of learning)

"Really hard in my efforts" (management of learning) 
Table 5

Process Factor-Effected Achievement

\begin{tabular}{lcccc}
\hline Input factors & Categorization & $f$ & $\%$ & $\%$ cumulative \\
\hline Completion of standard tasks & Attendance at lessons & 14 & 5.3 & 9.8 \\
Learning process & Completing assignments & 11 & 4.1 & 48.1 \\
& Learning optimization & 128 & 25.6 & 90.2 \\
& Management of learning & 68 & 22 & 2.6 \\
& Use of learning strategies & 7 & 1.1 & 1.1 \\
& Activity in class & 3 & 3 & $100 \%$ \\
\hline
\end{tabular}

"Always do the job well, on time" (completing assignments)

"Start really diligently with learning" (learning regularly)

In addition to input and process factors, there were other factors which were seen as contributing to maximizing achievement, namely self-efficacy and purpose. Goals had the highest number of responses (73.9\%). This meant that 'input' factors and processes will produce maximum output if students have goals which direct their learning behavior. Thus goals, both personal and social, were seen as very important for achievement. A summary of the factors seen as contributing to maximizing achievement can be seen in Table 6 .

Based on the findings shown in Tables 4, 5, and 6, the factors influencing overall achievement can be seen in Table 7, which shows that the process factor returned the largest percentage (49.53\%). This means that the emphasis on the learning process was considered the most important matter for determining student achievement.

\section{Achievement Model for Undergraduate Stu- dents in Yogyakarta}

From the findings regarding the concept, and the factors influencing achievement, as previously described, the dynamics of achievement can be seen in Figure 3.

From Figure 3, it can be seen that there are three blocks, interpreted as 'inputs,' 'processes,' and 'outcomes'. One 'input' block consists of cognitive capacity, personal soft skills, and motivation, as supported by external factors. The 'process' block includes standard task completion and the learning process, with self-efficacy as a supporting factor. The third block, namely 'output', is basically the achievement itself, which will be maximal, with personal and social goals. High achievement will encourage development.
The main factor of the 'input' block is motivation, which determines the process of learning. Motivation may be supported by the personal skills of students, as well as being supported by external factors. Cognitive capacity, even though it is included in the 'input' block, does not affect motivation, but rather affects the learning process found in the next block.

The main factor in the 'process' block is the learning process, of which the completion of standard tasks is an integral part. Optimization of the learning process is largely influenced by the individual belief as to whether he or she can achieve more, generally referred to as self-efficacy. This block directly influences 'student achievement', found in the next block.

The third block, namely the 'output' block, contains the definition of achievement. High and low achievement is determined by how strong student goals are. Goals can be personal, which include personal targets and focus on lecture objectives, or social goals, the demands placed upon students in the social world, including fulfilling parental expectations and gaining social recognition. Students who have such goals in the learning process will produce more creditable achievements than students without such goals. In the

Table 6

Booster Factors Contributing to Maximizing Achievement

\begin{tabular}{lccr}
\hline Factor & Categorization & $f$ & \% Cumulative \\
\hline Self-efficacy & Belief to be more & 23 & 26.1 \\
Goal & Personal goals & 53 & 73.9 \\
& Social goals & 12 & 100 \\
\hline
\end{tabular}

\section{Table 7}

Factors Affecting Achievement

\begin{tabular}{lcr}
\hline Factor & $f$ & $\%$ \\
\hline Input & 183 & 34.08 \\
Process & 266 & 49.53 \\
Booster & 88 & 16.39 \\
Total & 537 & $100 \%$ \\
\hline
\end{tabular}




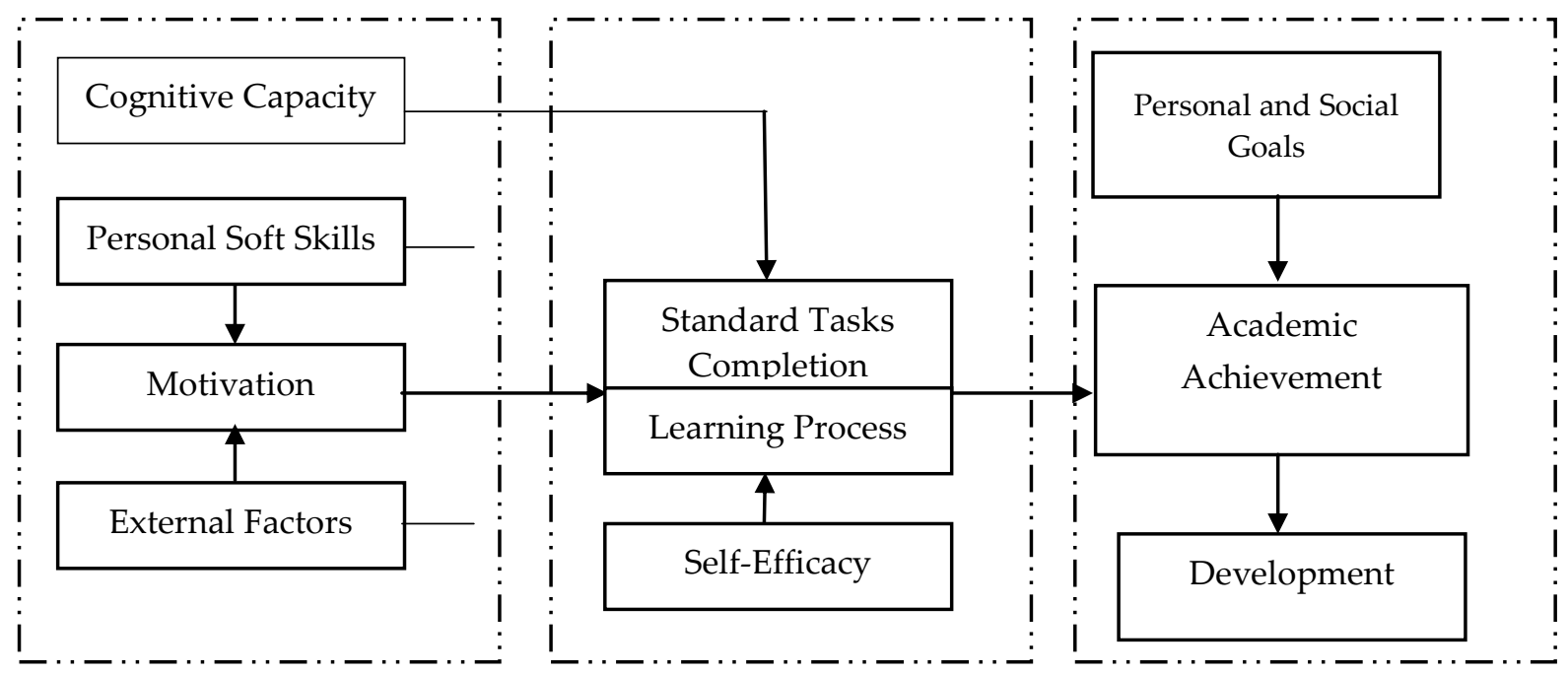

Figure 3. Achievement model for undergraduate students in Yogyakarta.

third block there is also the factor of development, which is a manifestation of more desirable achievement.

\section{Discussion}

Using indigenous psychology analysis, this study aimed to explain concepts, affecting factors, and the attainment of achievement, from the perspective of undergraduate students. The results of this study show that achievement can be classified as belonging to 'input,' 'process,' or 'outcome.' 'Input' categories are conditions sourced both internally and externally from students, and may, or not, include student activities, where all conditions are related to achievement factors. This category consists of motivation, personal skills, self-efficacy, cognitive capacity, and external conditions. The 'process' category covers the activities performed by the student, which drives him or her towards achievement. This category includes standard task completion and the learning process. The 'outcome' category covers attainments, goals, and student development.

The concept of achievement found in this study consists of: (1) the definition of achievement; and (2) the criteria of achievement. The definition of achievement is attainment. The uniqueness found in this definition, compared with those in previous studies such as those reviewed by York, Gibson, and Rankin (2015) is the inclusion of non-academic achievement and the predominance of competition with others within the definition. The non-academic achievement found in this study covers attainment in sport and art. In addition to attainment in the academic area, respondents perceived mastery in sport and art as achievements in the educational setting. Appreciation in the non-academic area seems to be given some emphasis, so that academic grades are not the only determinant for achievement. An example of this achievement is the participation, and gaining recognition in, art, or in sporting competition.

This study show that achievement also be determined from how much better one person is than another. In the culture where the respondents live, perceptions about achievement cannot be separated from comparison with someone else in the group. Students are perceived as achievers if they have ranked at the top and are seen as superior, compared to others. In their previous scholastic system, tertiary students experienced a class ranking system, based on grades achieved. The system still continues at university level. Even though the class ranking system is no longer officially in use, it is still practiced, when students compare their GPAs, one with another.

An explanation of these findings cannot be separated from the context in which this data was collected, from tertiary students in a private university in Yogyakarta, one of the Eastern countries. The education culture in the Eastern world strongly emphasizes conformity and adherence to the rules made by higher authorities. These rules are generally made with the aim of producing perfect students (Dahlin \& Regmi, 2000). This culture may explain the findings in this study, where achievement is measured by the comparison of one set of grades with another. This comparison is determined by a higher authority, namely the lecturer or the education administration. This cannot be found 
in Western world achievement theory, where there is more emphasis on individualism, and there is freedom of expression, without the comparison of one person with another (Hassan, \& Jamaludin, 2010).

On the criteria of an achiever, this study found a correlation between achievement and personal and social goals, and also development. This result is unique, as is the presence of social goals in the criteria of an achiever. Social goals, in this result, include compliance with parental expectation, and social acknowledgment. The context in which this study was conducted is one of a collectivist culture. Harmony with the environment is a characteristic of lives of people in a collectivist culture, so that students tend to adjust to others, in order to minimize judgment from others. This is different from the individualist culture in the West, where people are not afraid of being different from others, or making mistakes. Teacher-student relations are more open in a culture of individualism, so students do not always have to meet the expectations of teachers and parents at home (Niyozov \& Pluim, 2009), whereas in a collectivist culture, fulfilling social expectations is considered important.

This study found two factors affecting achievement, namely those of 'input' and of 'process'. 'Input' factors consist of cognitive capacity, personal skills, motivation, and external conditions. This cognitive capacity found in this study is not something new. Previous research showed a positive correlation between cognitive skills and academic achievement (Finn, Kraft, West, Leonard, Bish, Martin \& Gabrieli, 2014). Cognitive capacity in this study consists of thinking ability and memory skills. Working memory has been found to correlate with academic achievement (Alloway \& Alloway, 2010; Alloway \& Passolunghi, 2011). How cognitive capacity influences academic achievement is something needing to be explored.

Personal skills are non-technical skills, predicting the success of a person in attaining something. Nontechnical skills in this study may support students in their academic learning activities, so that an optimal achievement can be reached. The most responses in the personal skills classification were for self-management in learning. Previous research addressed this term as self-regulated learning, that is active learning participation, meta-cognitively, motivationally, and behaviorally (Zimmerman, 1986 in Zimmerman \& Schunk, 2008). There is evidence that self-regulation predicts learning motivation, the use of learning strategies, and academic achievement (Schunk, Pintrich, \& Meece, 2008; Zimmerman, 2008; Zimmerman \& Schunk, 2008). The difference between the concept of self-management in this study, and the concept of self-regulated learning, is in its scope. The theory of self-regulated learning in the West has wider scope, covering thoughts, feelings, and actions. The self-management found in this study is limited to the management of actions, namely managing time to accomplish the various activities which students have to undertake.

Self-efficacy is a person's belief in his or her ability to do something to demonstrate performance (Bandura, 1994). Some studies in the Western world found that self-efficacy positively correlated with academic achievement (Bembenutty, 2009; Hodges, StackpoleHodges, \& Cox, 2008; Manzano-Sanchez, Outley, Gonzales, \& Matarrita-Cascante, 2018; Merolla, 2017; Patrick, Care, \& Ainley, 2011). In this study a concept similar to self-efficacy is the feeling of being able further to improve achievement and to believe that it should be better. These findings emerged from the results of personal evaluations by the respondents, who felt that the achievements attained at this time were not in accordance with their full abilities. In the situation of education in the culture of the East, as represented by students in Yogyakarta in this study, criticism of mistakes made by students is more common than appreciation for what students do correctly (Niyozov \& Pluim, 2009). This is different from the approach of lecturers in Western cultures, who tend easily to appreciate the work of students. This difference makes most students in Eastern cultures fail to become familiar with the concept of self-efficacy. Eastern culture teaches people to be humble and not to talk much, nor to show their abilities. People who are too sure of their own abilities are often regarded as arrogant, and not as well attuned to social norms.

In addition to internal factors, this study found external conditions affected learning achievement, through learning activities, which are summarized into four main categories, namely the characteristics of lecture material, lecturer characteristics, the number of nonacademic burdens, and the characteristics of friends. The characteristics of the course received the highest responses, meaning that the difficulty-easiness or interesting-boring qualities of the lecture material may determine whether students will proceed to attain academic achievement. Regarding the human factors, this study found the role of lecturers and friends played a part. This finding is somewhat different from the previous findings by Orrock and Clark (2015) which mentioned the role of the family, in addition to those of teachers and friends, as factors influencing the success of the learning of students.

The dynamics of the acquisition of achievement 
found in this study are explained in the following sentences. There are three parts to the dynamics of student achievement, namely 'input', 'process', and 'outcome', and three supporting factors in each of these parts. The factors included in the 'input' part are personal skills, motivation, and external conditions, with cognitive capacity as a supporter. The 'process' section includes fulfilling standard tasks and the learning process, with self-efficacy as a supporting factor. The third part, namely 'output', is basically achievement itself, where this achievement can then be further developed in a wider area, with personal and social goals as a supporting factor.

The 'input' factors have their own dynamic, in which motivation plays a central part, correlating with the 'process' part. High and low motivation is affected by personal skill factors, which are supported by cognitive capacity, and by external factors. Amongst all the 'input' factors found in this study, motivation had the largest number of responses, with learning intention as the operational form of such motivation, in the highest number of responses. Motivation is a booster to certain goals (Schunk, Pintrich, \& Meece, 2008). Many theories explore motivation, from that of fulfilling basic physical needs to believing in the role of thoughts and beliefs as the main form of motivation. Many studies considered the effect of motivation on academic achievement (for example, Al-Harthy \& Was, 2010; Bernaus \& Gardner, 2008; Cloud, Noureen, \& Naz, 2011; Jen \& Yong, 2013; Karimi \& Venkatesan, 2009; Lemos \& Veríssimo, 2014; Onuka \& Durowoju, 2011). Motivation does not involve a tangible activity, so its role in academic achievement is not direct. More concrete activities are also needed, both physical and mental, to attain academic achievement. These activities are highly dependent on the presence or absence of motivation in students. In this study, the activities found included; participation in classroom learning activities, completing assignments, managing learning activities, using learning strategies, studying seriously, and seeking help when facing difficulties in learning.

The 'process' section includes completing standard tasks and the learning processes, with self-efficacy as a supporting factor. Among all the 'process' factors, optimization of learning was the response with the highest number of returns, and this was followed by learning management. Learning optimization in this study included activities reflecting the maximum mobilization of all abilities while learning, and employing more effort in conducting learning activities, not merely working for just minimal learning demands.
The forms of learning management in this study are; good planning for learning activities, using time efficiently, learning not only to pass exams, independence in learning, not depending only on lecturer instructions, and not allowing the completion of tasks to be delayed. Optimizing learning and managing learning in this part of the process reflects an active learning involvement. This study found that active involvement in learning will produce better results if supported by self-efficacy, that is a belief in the need to produce something more. The concept which tends to be similar to this finding is the concept of self-regulated learning, which is essentially the involvement of students in choosing and applying learning strategies to achieve goals, based on self-efficacy.

The third part, namely 'output', is basically the academic achievement itself, with personal and social goals orientation as its supporting factors. Students who have initial goals, both personal and social goals, are students who indulge in such deep learning activities that their learning outcomes are also better. In this study, personal goals consist of target goals and continued focus on those goals, while social goals include the tendency to fulfill parental expectations and receive social recognition for what is achieved. In some literature, personal and social goals orientation is part of motivational theory (DeShon \& Gillespie, 2005; Huang, 2011). Goal orientation is interpreted as students having the goal of engaging in academic activities according to the standards used to measure performance (Friedel, Cortina, Turner, \& Midgley, 2010). Individual goals can be considered as driving factors for doing something. However, in the learning area, in many formal education institutions, many learners seem to have some motivation, which shows in the learning activities they carry out, but sometimes they do not have any specific goal. This happens when the learning process runs mechanically, and the learner merely completes scheduled academic routines, without really understanding what he is doing. It may therefore be said that this goal has an added value to the achievement of better performance, which is found in only a few learners, and this is what distinguishes between learners who are able to attain better achievements, and those who are not.

\section{Limitations}

The discussions and the practices of performance appraisal in higher education involve not only students, but also lecturers. Lecturers may have different perspectives on achievement, though the sample in this 
study is limited to undergraduate students of only one university. Inevitably there is a weakness in regard to representation.

\section{Conclusion}

Results of this study show that the concept of achievement from the perspective of undergraduate students is divided into definitions of achievement, and criteria to be considered as achievements. The definition of achievement from the perspective of Asian students is attainment, which has a uniqueness in the emergence of non-academic achievements and excellence in competition with others as aims. The criteria to be considered as an achiever include compliance with goals (both personal and social) and the element of development. Compliance with social goals as a criterion for one to be considered as an achiever is another uniqueness found in this study. These findings typically appear in a collective society where the judgments of others are very important, and this can be an educational goal. In the result concerning factors influencing achievement, there are 'input' and 'process' factors. 'Input' factors consist of personal capacities, whereas 'process' factors consist of the learning process. This result is in line with the results of previous studies, but the presence of external conditions in these factors is unique to the culture in which this research was conducted. The dynamic of achievement starts from 'input,' which consists of cognitive capacity, personal skills, motivation, and external conditions, which drive academic learning behaviors with the encouragement of self-efficacy. This dynamic encourages optimal learning achievements, in the presence of personal and social goals.

\section{References}

Al-Harthy, I. S., \& Was, C. A. (2010). Goals, efficacy and metacognitive self-regulation. International Journal of Education, 2, 1-20.

Alloway, T. P., \& Alloway, R. G. (2010). Investigating the predictive roles of working memory and IQ in academic attainment. Journal of Experimental Child Psychology, 106(1), 20-29.

Alloway, T. P., \& Passolunghi, M. C. (2011). The relationship between working memory, IQ, and mathematical skills in children. Learning and Individual Differences, 21(1), 133-137.

Arum, R., \& Roksa, J. (2011). Academically adrift: Limited learning on college campuses. University of Chicago Press.

Astin, A. W. (1991). Assessment for excellence: The philosophy and practice of assessment and evaluation in higher education. Phoenix, AZ:: Oryx Press.

Awan, R. U. N., Noureen, G., \& Naz, A. (2011). A study of relationship between achievement motivation, self concept and achievement in English and mathematics at secondary level. International Education Studies, 4(3), 72-79.

Bandura, A. (1994). Self-efficacy. In V. S. Ramachaudran (Ed.), Encyclopedia of human behavior (Vol. 4, pp. 71-81). New York: Academic Press.

Bembenutty, H. (2009). Academic delay of gratification, self-regulation of learning, gender differences, and expectancy-value. Personality and Individual Differences, 46(3), 347-352.

Bernaus, M., \& Gardner, R. C. (2008). Teacher motivation strategies, student perceptions, student motivation, and English achievement. The Modern Language Journal, 92, 387-401.

Choi, N. (2005). Self-efficacy and self-concept as predictors of college students' academic performance. Psychology in the Schools, 42(2), 197-205. https:// doi.org/10.1002/pits.20048

Cole, M. (2009). Using Wiki technology to support student engagement: Lessons from the trenches. Computers \& Education, 52(1), 141-146.

Dagnew, A. (2017). The relationship between students' attitudes towards school, values of education, achievement motivation and academic achievement in Gondar Secondary Schools, Ethiopia. Research in Pedagogy, 7(1), 30-42.

Dahlin, B., \& Regmi, M. P. (2000). Ontologies of knowledge, East and West-A comparison of the views of Swedish and Nepalese students. International Journal of Qualitative Studies in Education, 13(1), 43-61.

Dhaqane, M. K., \& Afrah, N. A. (2016). Satisfaction of students and academic performance in Benadir University. Journal of Education and Practice, 7 (24), 59-63.

DeFreitas, S. C., \& Bravo Jr, A. (2012). The influence of involvement with faculty and mentoring on the self-efficacy and academic achievement of African American and Latino college students. Journal of the Scholarship of Teaching and Learning, 12(4), 1-11.

DeShon, R. P., \& Gillespie, J. Z. (2005). A motivated action theory account of goal orientation. Journal of Applied Psychology, 90(6), 1096-1127.

Finn, A. S., Kraft, M. A., West, M. R., Leonard, J. A., Bish, C. E., Martin, R. E., ... \& Gabrieli, J. D. (2014). 
Cognitive skills, student achievement tests, and schools. Psychological Science, 25(3), 736-744.

Flashman, J. (2012). Academic achievement and its impact on friend dynamics. Sociology of Education, 85(1), 61-80.

Friedel, J. M., Cortina, K. S., Turner, J. C., \& Midgley, C. (2010). Changes in efficacy beliefs in mathematics across the transition to middle school: Examining the effects of perceived teacher and parent goal emphases. Journal of Educational Psychology, 102 (1), 102.

Galyon, C. E., Blondin, C. A., Yaw, J. S., Nalls, M. L., \& Williams, R. L. (2012). The relationship of academic self-efficacy to class participation and exam performance. Social Psychology of Education, 15(2), 233-249.

Goguen, L. M. S., Hiester, M. A., \& Nordstrom, A. H. (2010). Associations among peer relationships, academic achievement, and persistence in college. Journal of College Student Retention: Research, Theory \& Practice, 12(3), 319-337.

Gurin, P., Dey, E., Hurtado, S., \& Gurin, G. (2002). Diversity and higher education: Theory and impact on educational outcomes. Harvard Educational Review, 72(3), 330-367.

Hakim, L. N. (2014). Ulasan konsep: Pendekatan psikologi indijinus. Jurnal Aspirasi, 5(2), 165-172.

Hassan, A., \& Jamaludin, N. S. (2010). Approaches $\&$ values in two gigantic educational philosophies: East and West. Online Educational Research Journal, 1(2), 1-15.

Hodges, C. B., Stackpole-Hodges, C. L., \& Cox, K. M. (2008). Self-efficacy, self-regulation, and cognitive style as predictors of achievement with podcast instruction. Journal of Educational Computing Research, 38(2), 139-153.

Huang, C. (2011). Achievement goals and achievement emotions: A meta-analysis. Educational Psychology Review, 23(3), 359.

Jen, C. S., \& Yong, B. C. S. (2013). Secondary school students' motivation and achievement in combined science. US-China Education Review, 3(4), 213-228.

Karimi, A., \& Venkatesen, S. (2009). Mathematics anxiety, mathematics performance and academic hardiness in high school students. International Journal of Educational Science, 1, 33-37.

Kim, U., Yang, K. S., \& Hwang, K. K. (Eds.). (2006). Indigenous and cultural psychology: Understanding people in context. Springer Science \& Business Media.

Lemos, M. S., \& Verissimo, L. (2014). The relationships between intrinsic motivation, extrinsic motivation, and achievement, along elementary school.
Procedia-Social and Behavioral Sciences, 42, 930-938.

Manzano-Sanchez, H., Outley, C., Gonzalez, J. E., \& Matarrita-Cascante, D. (2018). The influence of selfefficacy beliefs in the academic performance of Latina/o students in the United States: A systematic literature review. Hispanic Journal of Behavioral Sciences, 40(2), 176-209.

Marginson, S., \& Mollis, M. (2000). Comparing National Education Systems in the Global Era. Australian Universities' Review, 42(2), 53-63.

Merolla, D. M. (2017). Self-efficacy and academic achievement: The role of neighborhood cultural context. Sociological Perspectives, 60(2), 378-393.

Niyozov, S., \& Pluim, G. (2009). Teachers' perspectives on the education of Muslim students: A missing voice in Muslim education research. Curriculum Inquiry, 39(5), 637-677.

Onuka, A. O. U., \& Durowoju, E. O. (2011). Motivation and gender as determinants of achievement in senior secondary school economics. European Journal of Educational Studies, 3(2), 209-216.

Orrock, J., \& Clark, M. A. (2015). Using systems theory to promote academic success for African American males. Urban Education. https://doi.org/10. 1177/ 0042085915613546

Patrick, L., Care, E., \& Ainley, M. (2011). The relationship between vocational interests, self-efficacy, and achievement, in the prediction of educational pathways. Journal of Career Assessment, 19(1), 61-74.

Schmid, R. F., Bernard, R. M., Borokhovski, E., Tamim, R., Abrami, P. C., Wade, C. A., ... \& Lowerison, G. (2009). Technology's effect on achievement in higher education: A stage I meta-analysis of classroom applications. Journal of Computing in Higher Education, 21(2), 95-109.

Schunk, D. H., Pintrich, P. R., \& Meece, J. L. (2008). Motivation in education: Theory, research, and applications (3rd ed.). Upper Saddle River, N.J.: Pearson/Merrill Prentice Hall.

Singh, A. K. (2002). The comprehensive history of psychology. Delhi: Motilal Banarsidass Publisher Ltd.

Turingan, J. P., \& Yang, Y. C. (2009). A cross-cultural comparison of self-regulated learning skills between Korean and Filipino college students. Asian Social Science, 5(12), 3.

Ugwu, C. C. (2017). Relationship between social support and academic performance among undergraduate students of Madonna University, Nigeria. Global Journal of Applied, Management and Social Sciences, 13.

Valiente, C., Eisenberg, N., Spinrad, T. L., Haugen, R. G., Thompson, M. S., \& Kupfer, A. (2013). Ef- 
fortful control and impulsivity as concurrent and longitudinal predictors of academic achievement. The Journal of Early Adolescence, 33(7), 946-972. Von Stumm, S., Hell, B., \& Chamorro-Premuzic, T. (2011). The hungry mind: Intellectual curiosity is the third pillar of academic performance. Perspectives on Psychological Science, 6(6), 574-588.

York, T. T., Gibson, C., \& Rankin, S. (2015). Defining and measuring academic success. Practical Assessment, Research \& Evaluation, 20(5), 2.

You, S., Hong, S., \& Ho, H. Z. (2011). Longitudinal effects of perceived control on academic achieve- ment. The Journal of Educational Research, 104 (4), 253-266.

Yusuf, A. (2002). Interrelationships among academic performance, academic achievement and learning outcomes. Journal of Curriculum and Instruction, 1(2), 87-96.

Zimmerman, B. J., \& Schunk, D. H. (2008). Motivation: An essential dimension of self-regulated learning. In D. H. Schunk \& B. J. Zimmerman (Eds.), Motivation and self-regulated learning: Theory, research, and applications (pp. 1-30). Mahwah, NJ, US: Lawrence Erlbaum Associates Publishers. 